DOI https://doi.org/10.30525/978-9934-26-046-9-50

\title{
РАЗРАБОТКА КОНСТРУКЦИИ АВТОНОМНЫХ ТЯГОВЫХ МОДУЛЕЙ ДЛЯ ПЕРСПЕКТИВНЫХ УСЛОВИЙ ЭКСПЛУАТАЦИИ НА ЖЕЛЕЗНОДОРОЖНОМ ТРАНСПОРТЕ
}

\author{
Франтишек Буреш \\ ORCID ID: 0000-0003-2171-7476 \\ член правления \\ AO «Украинские железнье дороги» \\ г. Киев, Украина
}

Повышение эффективности использования транспортных средств с учетом перспективных условий эксплуатации является одним из направлений развития транспортного машиностроения. Поэтому технические решения, направленные на решение данной научнотехнической задачи, являются актуальными для как в целом для наземного транспорта, так и для железнодорожного транспорта в частности.

В основном, конструктора и исследователи уделяют внимание совершенствованию механической части тяговых средств железнодорожного транспорта, а именно локомотивов [1-4], при этом ограничиваясь рассмотрением только динамических или прочностных качеств этих транспортных средств. Разработка же конструкций тяговых транспортных средств для автономного и автоматизированного использования требует учета не только перспективных условий эксплуатации в виде повышения скоростей движения, но и учета смарттехнологий, позволяющих полностью сделать автоматизированным процесс функционирования и ведения составов по железным дорогам.

Конструкция автономного транспортного средства выбрана по результатам предварительных исследований, проведенных автором, по определению характеристик конструкции тягового средства для использования при обеспечении перевозки железнодорожных поездов по направлению Китай - Евросоюз. При этом учитывались как механические особенности конструкции, так и тягово-энергетические параметры автономных тяговых модулей.

Конструкция представлена в виде следующих основных элементов: кузов, тележки, колесные пары, силовая система, система жизнеобеспечения, система диагностики, тормозная система и система 
управления. Каждая из названых систем состоит из нескольких подсистем, которые функционально дополняют друг друга в эксплуатации.

Основными конструктивными элементами двухосной тележки являются колесные пары и рама. Двухосная тележка оснащена индивидуальным тяговым приводом на каждую ось с опорно-осевым подвешиванием двигателя. Конструкция тележки имеет буксовое и центральное рессорные подвешивания с использованием упругих элементов и гасителей колебаний. Буксовое рессорное подвешивание обеспечивает опору рамы тележки на каждую буксу через два пакета цилиндрических пружин. Для демпфирования вертикальных колебаний параллельно пружинам между буксами и рамой тележки установлено по одному гидравлическому гасителю колебаний на буксовый узел. Кузов опирается на рамы тележки через комплекты двухрядных цилиндрических пружин.

Наличие систем автономного жизнеобеспечения и резервной энергетической установки позволяет обеспечивать функционирование тягового модуля без дополнительного сервисного обслуживания в течении периода до 10 суток или 240 моточасов и более, что позволяет преодолевать расстояния более 12000 км с учетом возможных технических остановок, связанных с технологией работы железных дорог и графиком движения поездов. Конструкционная скорость движения на 30-40 \% выше, чем у обычных грузопассажирских мультисистемных локомотивов.

Таким образом, в работе предложено описание технических решений конструкции четырехосного автономного тягового модуля для осуществления магистральной и маневровой работы на железнодорожном транспорте с применением инновационных технологий по дизайну, управлению и диагностике. Данная конструкция позволяет обеспечивать транспортировку как грузовых, так и пассажирских поездов с учетом действующего графика движения и соблюдения функциональной совместимости с различными системами инфраструктуры железных дорог.

\section{Литература:}

1. Myamlin S., Luchanin M., Neduzha L. Construction Analysis of Mechanical Parts of Locomoties // TEKA. Commision of Motorization and Power Industry in Agriculture. - 2013. - Vol. 13, № 3. - P. 162-169.

2. Мямлин С. В., Лунис О., Недужая Л. А. Особенности конструкции ходовых частей тягового подвижного состава // Наука та прогрес транспорту. - 2017. - № 3 (69). - С. 130-146. DOI: $10.15802 /$ stp2017/104824 
3. Мямлин С. В., Недужая Л. А. Совершенствование конструкции ходовых частей локомотивов // Наука та прогрес трансп. Вісн. Дніпропетр. нац. ун-ту залізн. трансп. ім. акад. В. Лазаряна. - 2013. № 5 (47). - C. 124-136. DOI: 10.15802/stp2013/17977

4. Spiryagin M., Wolfs P., Cole C., Spiryagin V., Sun Y. Q., McSweeney T. Design of Mechanical Systems of Locomotives from: Design and Simulation of Heavy Haul Locomotives and Trains. - CRC Press, 2016. -477 p.

DOI https://doi.org/10.30525/978-9934-26-046-9-51

\title{
ВИКОРИСТАННЯ СТАЛЕЗАЛІЗОБЕТОННИХ ПРОГОНОВИХ БУДОВ ДЛЯ ПОСТКОНФЛІКТНОГО ВІДНОВЛЕННЯ ЗРУЙНОВАНОЇ ТРАНСПОРТНОЇ ІНФРАСТРУКТУРИ
}

\author{
Гернич М. В. \\ викладач кафедри військової підготовки спечіалістів \\ Державної спеціальної служби транспорту \\ Дніпровський національний університет залізничного транспорту \\ імені академіка Всеволода Лазаряна \\ Ключник С. В. \\ кандидат технічних наук, \\ старший викладач кафедри транспортної інфраструктури \\ Дніпровський національний університет залізничного транспорту \\ імені академіка Всеволода Лазаряна \\ м. Дніпро, Украӥна
}

Набутий за тисячоліття досвід післявоєнної відбудови засвідчує, що неефективність заходів, спрямованих на відновлення зруйнованих бойовими діями територій та економічних зв'язків, може призвести до повторення військових конфліктів [1]. На території України в наслідок ведення бойових дій було знищено та пошкоджено значну частину транспортної інфраструктури, зокрема малих та середніх залізничних мостів. Для відновлення у стислі терміни цих об'єктів пропонується розглянути можливість використання металевих балок тривалого зберігання (мобілізаційного резерву) виготовлених за типовими проектами. 